\title{
The innovation and productivity nexus in Malaysian manufacturing firms
}

\begin{abstract}
The study uses the Economic Census Data of 2011 to investigate the innovation-productivity nexus at firm level of Malaysia manufacturing firms. The nexus of innovation and the other determinants of productivity were examined through the augmented Cobb-Douglas production function and the outcomes were as expected. The major findings of the study confirmed that innovation plays a significant role in enhancing productivity in the manufacturing sector. Other than innovation, capital intensity, labour quality, foreign direct investment, and export are among the factors that contribute to higher productivity.
\end{abstract}

Keyword: Firm level data; Innovation; Exports; Productivity; Malaysia; Manufacturing industry; Capital intensity; Labour quality; Foreign direct investment; FDI 